\title{
Bożena Klimczak
}

Wrocław University of Economics

Faculty of Economic Sciences

e-mail: bozena.klimczak@ue.wroc.pl

\section{The impact of economic studies on students' morality level*}

\begin{abstract}
Since the beginning of the 1980s, a study has been conducted among students of economics in the United States regarding their propensity for cooperation, philanthropy and keeping promises. Regardless of the methods used, the research results have shown lower readiness for cooperation among students of economics in comparison to students of other disciplines. Moreover, the results are even worse after completing a microeconomics course. Based on these findings, two hypotheses have been formulated: the auto-selection hypothesis and the indoctrination hypothesis.

The aim of the paper is to formulate implications regarding the indoctrination hypothesis. A massive attendance at economic studies in Poland is an argument against the auto-selection hypothesis. However, unless the research is completed, this hypothesis cannot be rejected. The indoctrination hypothesis is more attractive due to the special cognitive and moral condition of post-communist society which economic studies lecturers are members of and due to the economic situation of higher education institutions. These circumstances which accompany the studying of economics in Poland favour, firstly, the introduction of highly specialised curricula which do not prepare students for understanding economic activity as a means for good life. Secondly, economic knowledge is interpreted by lecturers as a set of instructions to manipulate market players. Thirdly, lecturers' attitudes and activities reflecting the principle that what is not legally prohibited is allowed are "awarded" with a higher financial status.
\end{abstract}

\footnotetext{
* The article is an updated version of the paper published in Polish in the Annales. Ethics in Economic Life, 8(2), 11-24.
} 
These implications will be made probable by the analysis of the curricula and content of lectures in economic schools. Attention will be mostly focused on microeconomics; the main "defendant" accused of indoctrination in the American studies.

Keywords: morality level, experimental research of students' morality level, impact of microeconomic curricula on students' morality level

JEL Classification: A20

\section{Introduction}

Since the beginning of the 1980s, research has been carried out among students of economics in the United States concerning their propensity for cooperation and philanthropy, as well as their knowledge of basic moral concepts such as justice, fairness and honesty. Regardless of the methods applied, the results obtained indicate lower readiness for cooperation among students of economics compared to students of non-economic disciplines and show the deterioration of the results after taking a microeconomics course. On this basis, two hypotheses have been formulated: the auto-selection hypothesis and the indoctrination hypothesis.

The aim of the paper is to discuss the indoctrination hypothesis on the basis of the conducted research that comprised experimental games in which students participated. Knowledge of economic games and experimental conditions can shed some light on the results of the study carried out. The research results themselves are not as relevant as the question concerning the possibility of indoctrination by means of the content of economic sciences taught and by showing the image of selfish homo economicus. The sources of indoctrination in economic studies may be textbooks and other didactic materials as well as the person of the lecturer (the lecturer's knowledge, views and teaching skills). Therefore, it is advisable to examine the content of textbooks on economics, especially in the area of microeconomics, in which the motivations and characteristics of homo economicus are discussed due to the possibility of indoctrination consisting in promoting selfish attitudes and actions. The content of these textbooks will be analysed in the context of discussions and doubts concerning the object of economics, its methods of analysis and status of a positive science.

The first part of the paper will discuss experiments conducted among American students: the properties of selected games and their use in economics studies as well as their results in the light of controversy about the use of experiments in economics. The second part of the paper is devoted to the discussion of the content of economics textbooks in terms of: definitions and characteristics of economics, its methods of analysis, as well as the place of psychological and philosophical assumptions regarding homo economicus and the presentation of the consumer 
choice theory. Basic textbooks used most often for teaching economics and microeconomics in the United States will be the subject of the analysis conducted. The choice of textbooks written by American authors stems from several reasons. First of all, the study on economics students' propensity for cooperation and honesty has been carried out at American universities. Secondly, the United States of America became the centre of development of mainstream economics in the $20^{\text {th }}$ century. Thirdly, the template for teaching economics has been developed there. In the third part of the paper, the content of textbooks will be critically analysed in terms of completeness of economic knowledge and discursiveness of its message. In the conclusions, the implications of the hypothesis about indoctrination in teaching economics in Poland will be formulated.

\section{Research on the impact of economic studies on students' morality level}

In the United States, several studies have been inspired by an experiment conducted in 1981 at the University of Wisconsin (Marwell \& Ames, 1981). It concerned the problem of the free rider. In standard economics, there exists a strong hypothesis concerning the avoidance of cooperation related to the public good. It is assumed that people focused on their self-interest make a rational calculation of benefits and costs derived from cooperation which results in the public good. If coercion or other incentives to co-create the public good are not used, rational egoists will avoid cooperation, expecting benefits from the public good at zero private cost (Hardin, 1968; Olson, 1965). Marwell and Ames created such a situation and examined how students of different disciplines made the allocation of private resources between the private and public use. The return on funds for the private purpose was doubled (dollar for dollar). The return on funds for the public purpose was greater, and then it was evenly distributed among the experiment participants. In eleven groups of non-economic students, the results were similar: approx. $49 \%$ of the resources were allocated to the public purpose. However, in the twelfth group, consisting of first-year students of economics, only about $20 \%$ of resources were allocated to the public purpose. On the subject of fairness,

more than one-third of the economists refused to answer the question regarding what is fair, or gave very complex, uncodable responses. It seems that the meaning of "fairness" in this context was somewhat alien to this group. Those who did respond were much more likely to say that little or no contribution was "fair". In addition, the economics graduate students were about half as likely as other subjects to indicate that they were "concerned with fairness" in making their investment decision. (Marwell \& Ames, 1981)

The assessment of the value of these results requires consideration of various experiments regarding the free-rider hypothesis. Early experiments of Brubaker 
(1975) have pointed to the importance of the conditions under which public action is taken. He has formulated a weak hypothesis about the free-rider according to which the refusal to cooperate is not motivated by selfishness and greed, but by the fear of losing private resources. This hypothesis is confirmed by the research of Dawes from 1986 (Dawes, van de Kragt \& Orbell, 1990) and Samuelson et al. also from 1986, who studied free-riding as an effect of inefficient management of shared resources. Subsequent works of Ostrom (1990) and other economists from the institutional group confirm the importance of effective institutions in undertaking cooperation.

The experiment of Marwell and Ames was carried out at an early stage of research on free-riding in which a strong hypothesis prevailed concerning the influence of selfish calculation oriented towards a private objective on the decision on cooperation. Graduate-level economics students could know the hypothesis and its implications regarding the destructive impact of collective actions on markets, allocation efficiency and economic growth. In artificial conditions in which social norms and information about decisions of other participants were not taken into account, economics students used their free-riding knowledge strategically, unlike in real social life. It can be argued that the Marwell and Ames experiment does not prove students' different motivations but instead testifies to a different level of knowledge about free-riding.

An attempt to investigate the selfish motivation of economics students was made by Carter and Irons (1991) by means of the experimental "ultimatum" game used by Güth, Schmittberger and Schwarz in 1982. Two people participate in the game: the proposer of the allocation of a certain resource between the said proposer and the other person (the responder) who can accept or reject it. In the latter case, none of the participants receive anything. This game is used to study causes of conflict. It presents a potential conflict between the interests of the game participants. It is very simple, which allows one to study the motives guiding the participants of the game. In particular, the importance of reciprocity motivation can be studied. The standard economic theory, assuming common knowledge about rational egoism of the game participants, predicts that the offer will be close to zero and will not be rejected. In the Carter and Irons (1991) experiment, the offers of economics students amounted to an average of $\$ 3.95$ for $\$ 10$, while offers from students of other disciplines to $\$ 4.56$. The smallest amount accepted by economics students was $\$ 1.70$, while in the case of students of other disciplines it was $\$ 2.44$. The results of this experiment do not differ significantly from numerous subsequent studies (Falk, Fehr \& Fischbacher, 2003) conducted among different populations. Most often, offers a range between 0.4 and 0.5 of the total amount to be divided. Very rarely, there are offers below 0.2 . The most probable reason for this phenomenon is the fear of rejection of a lower offer. An offer ranging from 0.4 to 0.5 of the amount to be divided expresses, therefore, risk aversion and preferences for the reciprocity principle. A slightly lower offer of economics students does not necessarily prove their egoism, but rather a higher propensity for risk and a lack of ability to apply the reciprocity principle in the market and in enterprises. 
In the third experiment carried out by Frank, Gilovich and Regan (1993), the game called the prisoner's dilemma was used during the period when many of its various applications were already known. The authors of the experiment developed three versions of the game:

(1) a one-off game between two people who did not know each other and could not know their decisions in subsequent games. The participants of the game received a payment,

(2) a one-off game between two people who before the game, in a separate room, filled out a declaration about their decision in relation to each of the two other players in the group. Then the expenditures were calculated as the sum of: the results of the game with the first partner, and the results of the game with the second partner, providing a value drawn from a list of "positive and negative values". The players only learned the sum without its components. The aim of this solution was to prevent the game participants from deducing their partner's decision based on payoffs. This game had two variants:

(2a) the participants could promise to cooperate, but specific decisions were not disclosed,

(2b) the participants could learn their preferences by communicating for 30 minutes or for 10 minutes.

The results of the games are presented in Table 1.

Table 1. The results of "prisoner's dilemma" game in the student experiment

\begin{tabular}{|c|c|c|c|c|c|c|}
\hline & \multicolumn{2}{|c|}{ Game 1} & \multicolumn{2}{|c|}{ Game 2a } & \multicolumn{2}{|c|}{ Game 2b } \\
\hline & $\mathrm{C}$ & $\mathrm{R}$ & $\mathrm{C}$ & $R$ & $\mathrm{C}$ & $\mathrm{R}$ \\
\hline Economics students & $39.6 \%$ & $60.4 \%$ & $71.4 \%$ & $28.6 \%$ & $28.2 \%$ & $71.8 \%$ \\
\hline Students of other disciplines & $61.2 \%$ & $38.8 \%$ & $74.1 \%$ & $25.9 \%$ & $71.8 \%$ & $47.3 \%$ \\
\hline
\end{tabular}

Note. $\mathrm{C}=$ cooperation, $\mathrm{R}=$ refusal to cooperate. Adapted from "Does studying economics inhibit cooperation?" by R.H. Frank, T. Gilovitch, D.T. Regan, 1993, Journal of Economic Perspectives, 7(2), 159-177.

The results of these games are not surprising. Games played in artificial conditions in which participants cannot get to know each other and are not familiar with their mutual preferences in terms of values and motives for action do not provide grounds for generalisations. In addition, monetary payments are conducive to making selfish decisions, ${ }^{1}$ as there are no other incentives that determine or reduce payoffs such as satisfaction or shame. Other studies indicate that the ability to communicate and learn about the past of the game participants significantly limits selfish choices (Axelrod, 1984; Gilbert, 1996; Poundstone, 1992), as confirmed by the presented research. Therefore, only the result indicating the impact of economic education on the refusal to cooperate is of value. However, it should be taken into account that the awareness that it was an experiment that would not

\footnotetext{
${ }^{1}$ Sulejewicz does not mention any monetary payments in his paper (2002).
} 
cause any real harm might have been used to play a game with the payoff distributing organiser of the experiment. In real life, people cooperate not only for economic but also for social reasons, provided that they rationally evaluate the effects of permanent cooperation, i.e. if they are oriented not towards the outcome of a single game, but the process (Elster, 1985). This knowledge is provided, among others, by institutional economics which is not taught by mainstream economics. The authors of the "prisoner's dilemma" experimental game took this fact into consideration by conducting additional research in the form of a written interview on honesty among the students of economics who started a microeconomics course run by one of the two lecturers: the mainstream lecturer emphasising games in economics and the lecturer with an institutional orientation who limited the class content to the presentation of fundamentals of microeconomics. The students of the first lecturer showed a greater change in the level of cynicism (comparatively: before and after the course) than the students of the latter lecturer.

The authors of the discussed experiment emphasised in the analysis of their research results that they showed differences in the behaviour of economics students and students of non-economic disciplines. The authors could not, however, convincingly demonstrate the causative role of teaching economics in the selfish behaviour. The comparison of the results of these experiments shows, however, that among students of other disciplines, one could observe:

(1) differences in the risk propensity and ability to apply the reciprocity principle,

(2) differences in knowledge concerning the field of game theory.

This indirectly indicates the importance of economic knowledge in the selection of selfish strategies in the experiments conducted. Due to the artificiality of experimental situations, it cannot be said that economic studies influence the development of selfish motivations. However, one cannot reject the hypothesis that the content of and manner in which economic sciences, especially microeconomics, are taught exert some influence on students' views on the importance of selfish activities in achieving material success. ${ }^{2}$

\section{The image of homo economicus in American textbooks on economics}

In order to authenticate the presented hypothesis, the content of American textbooks on economics has been reviewed and analysed. The choice of American textbooks results from the discussed experiments which concerned American students. The most popular and widely used, not only in the United States but also in Europe, textbooks of Samuelson and Nordhaus (1985), Lipsey et al. (1990), Baumol and Blinder (1988), Varian (1995), Laidler (1981), Kamerschen et al.

\footnotetext{
${ }^{2}$ For more information, cf. Etzioni (2015).
} 
(1989) and Begg et al. (1993) have been chosen. These are textbooks presenting the standard approach to the object of economics and its methods of analysis along with the standard assumptions about homo economicus.

The standard approach to the object of economic research has been shaped by the famous essay by Robbins of 1932, who presented economics as the science which studies "human behavior as a relationship between ends and scarce means which have alternative uses."

In the examined textbooks, the central place is occupied by the description of limited resources and the need to make choices about their use. For example, Samuelson and Nordhaus (1985) state that:

Economics is the study of how men and society end up choosing, with or without the use of money, to employ scarce productive resources which could have alternative uses, to produce various commodities and distribute them for consumption, now or in the future, among various people and groups in society.

Kamerschen et al. (1989, p. 7) define economics in a similar manner, as the study of:

how people cope with scarcity-the pressing problem how to allocate their limited resources among their competing wants to satisfy as many of those wants as possible.

Lipsey et al. (1990, p. 4) succinctly inform that:

economics is the study of the use of scarce resources to satisfy unlimited human wants.

The adoption of Robbins' concept leads to the situation when the basic economic problem that homo economicus solves results from an insurmountable scarcity of resources. It would be difficult to deny that at a given time and under certain conditions people struggle with a scarcity of resources, however, ignoring human entrepreneurial spirit, inventiveness and desire to improve one's lot in life makes a depressing impression. In the definitions presented, economics seems to be a zero-sum game. The problem "what are the reasons for the wealth of nations?" posed by Smith has disappeared. In its place, the question arose as to how homo economicus makes choices among available options.

Making choices is the crux of deliberately undertaken economic activity. Robbins (1932, p. 95) assumed that the goals were given and resulted from people's mixed motivations:

our economic subjects can be pure egoists, pure altruists, pure ascetics, pure sensualists or — what is much more likely — mixed bundles of all these impulses. 
It should be assumed, therefore, that homo economicus is capable of rational choices and that economics is the rational choice theory. However, the assumption of rationality is explicitly absent from the textbooks examined, with the exception of the textbook by Baumol and Blinder (1988, p. 36) where one can read that:

a rational decision is a decision that best serves the purpose of the decisionmaker, no matter what the purpose is. The goals may be related to the desire of companies to maximise their profits, the government's desire to maximise the well-being of its citizens or to maximise the government's military might. The term "rational" cannot be an expression of approval or disapproval of any purpose.

The quoted fragment clearly informs why rationality was not included in the textbook concepts of choices made by homo economicus. Such a concept should be free from all judgments and assessments, from the so-called value judgements. Standard economics, as the choice theory free from values, i.e. as a positive science, deals — as Begg et al. (1993, p. 43) — say with "objective or scientific explanations of how the economy works".

Since the publication of Robbins, mainstream economists have aimed to eliminate psychological or philosophical assumptions about human aspirations and the structure of human intentions and motives for action. The image of homo economicus has departed from the real "baker, butcher, brewer" who, in order to act in their self-interest, serve other people and are embedded in their social environment:

It is not from the benevolence of the butcher, the brewer, or the baker, that we expect our dinner, but from their regard to their own interest. We address ourselves, not to their humanity but to their self-love, and never talk to them of our own necessities but of their advantage. (Smith, 1954, p. 14)

The concept of self-interest, which is a strong driving factor behind the motivation for human actions, freed by market exchange, is not generally discussed in American textbooks on economics. The following problems, which are constantly present in research and which have different answers, are also omitted:

(1) the problem of unintentional effects of intentional actions of homo economicus,

(2) the problem of conflicts between interests of individuals or groups of people,

(3) the problem of limited self-interest and mixed motivations.

In this situation, only Begg et al. (1993, pp. 28-29) speak of these issues:

Economics explains the process of allocating scarce resources between various competing uses [...]. This does not mean that economics does not deal with people as individuals. It also contains elements of the humanities. This is unavoidable, as only when human behavior can be studied and understood, economists are able to focus their research on the right issues. 
Mainstream economists, however, have focused on "proper problems", without seeking to explain human actions. This is seen, firstly, in abandoning the issue of rationality in the choice theory. ${ }^{3}$ Secondly, this is evidenced by the aspirations of Hicks, Samuelson, Arrow and Debreu to build the choice theory in which the assumptions about homo economicus take the form of axioms, as in mathematics, related to the rationality of choices (Rosenberg, 1992). The presentation of the consumer choice theory in the examined textbooks consists in replacing the purposefulness of choices with the ability to organise baskets of goods based on individual preferences. Baumol and Blinder (1988, p. 474) say:

Consumers will select the most desired combination of goods obtainable for their money [...].

Begg et al. (1993, pp. 141-144) present a similar view:

the consumer arranges baskets of goods, which reveals the preference for some baskets, and then chooses from among the available baskets the one that provides maximum utility.

A high level of skills related to building a cohesive set of preferences that are complete, transitive, reflexive and continuous is attributed to the consumer arranging baskets of goods. It seems that these preferences are neutral. However, a thorough analysis reveals hidden assumptions about the Archimedean nature of preferences and utility maximisation. The first characteristic is related to the assertion that:

Consumers obtain the greatest utility from their money by choosing combinations of goods whose marginal rate of substitution equals the ratio of their prices. (Baumol and Blinder, 1988, p. 474)

This means that the loss of a certain amount of a given good in the basket can be compensated by increasing the amount of another good. All preferences are therefore reducible; they do not have a hierarchical structure. Different intentions and desires are of equal importance to man, they are reduced to a common denominator, the so-called utility.

Utility is defined in the analysed textbooks as neutrally as possible, as satisfaction or happiness derived from consumption. Samuelson and Nordhaus (1985, pp. 411-412) present it as follows:

utility is an abstract concept used in economics to denote the subjective pleasure, usefulness, or satisfaction derived from consuming goods [...]. Utility is a simple and analytical construct used to explain how rational consumers allocate their limited income among goods that give them satisfaction or utility.

\footnotetext{
${ }^{3}$ The exception is the theory of rational expectations which has received many critical reviews.
} 
This quote shows an attempt to create the choice theory free from psychological or philosophical assumptions about man. To this end, it has been necessary to introduce procedural rationality, without assumptions about intentionality, volitionality and institutionality of human actions. Then, it can be formally argued that the rational action procedure replaces the optimisation goal. However, most economists choose individual utility and assume its maximisation. Maximising means that the consumer prefers more rather than less:

The consumer wishes to do as well as he can for himself, to select that consumption pattern out of those available to him that will yield the highest possible level of satisfaction - he wishes to maximize his utility. (Laidler, 1981, p. 15)

The consumer seeks to maximize his utility. (Kamerschen, McKenzie, Nardinelli, 1989, p. 152)

In standard economics, it is widely accepted that consumers maximise utility because they prefer to consume more rather than less. Let us assume that this is just a convenient concept, useful for explaining choices. It is, however, associated with two possibilities:

1) one adopts a utilitarian concept of searching for the truth due to its utility for most people. If market research reveals preferences for more rather than less, then these revealed preferences are useful for explaining choices;

2) preferences are selfish because a given person's utility depends on this person's consumption and not the consumption of other people. The concept of utility taking into account satisfaction derived from consuming purchased and donated goods by other people does not appear in the analysed textbooks. At most, it is sometimes claimed that people are isolated and, therefore, their preferences are neutral.

The attempt to neutralise economics by separating it from value has been neither successful nor consistently taught in the analysed textbooks. Therefore, the reference to hedonism made by Edgeworth and Jevons cannot be accidental.

The presentation of the concept of economics and its basic assumptions about homo economicus results in a different picture from the one intended by the authors of the textbooks studied. Since the publication in 1871 of Theory of Political Economy by Jevons, who wrote that "to maximize pleasure is the problem of economics" and that the market theory is "the mechanics of utility and self-interest" (1871, p. 46), there has been no major change in this respect. According to Begg, Dornbusch and Fischer, economic activity is so simple that "even rats can do it" (1993, p. 157). The authors thus referred to an experiment showing that a white rat had the ability to choose between cocktail and beer based on the difference in price. 


\section{Critical reflections}

In the light of the presented "textbook" image of homo economicus who always prefers more rather than less, seeks to maximise his own utility and is focused on ordering his own preferences, it can be concluded that the results of the discussed experiments show adequate knowledge on the part of economics students. It is, however, worth considering the duties of a microeconomics lecturer, who, as demonstrated by the last of the discussed experiments, can play an important role. This role depends on his or her knowledge of debates concerning the object of economics and its methods of analysis, especially discussions that deal with the explanation of economic activity. The authors of the analysed textbooks often draw the reader's attention to explanation, while Samuelson's concept of economics as a descriptive science is the most widespread. The competing axiomatic approach to economics as the choice theory is incorporated into the description of revealed preferences. If a given lecturer does not have in-depth knowledge about various concepts of explanation, i.e. the lecturer does not distinguish such concepts and separate them from the description, it results in an incoherent lecture from which emerges the image of not really a man and not really a rat making choices for the sake of sensual pleasure.

In addition to utility and preferences, the analysed textbooks describe desires, wants and needs. These concepts are not explained, though they are very important. The lack of definition is replaced by the assumption that needs, tastes, and preferences are given. This is the so-called taste model proposed by Hume (1963, Vol. III, Section I). It is a model that assumes that people build their lives by striving to fulfil their desires which are subjective and emotional. People, therefore, think that a life of value is the kind of life they want. By accepting that man is a biological and psychological being, it can be argued that desires are permanent and given.

The taste model is built on the clear distinction between facts and values called Hume's guillotine. The distinction between facts/values is also accompanied by oppositions between is/should, reason/feeling and understanding/reacting. Therefore, the taste model does not attribute the property of rationality to individual desires and tendencies. What we want is valuable subjectively and emotionally. People strive to fulfil their desires because they want what is good for them according to what they imagine and feel is good.

If we analyse the consumer choice theory in the light of the taste model, then some inconsistencies that I drew attention to in the third part of the paper are clarified. Maintaining rationality as procedural rationality is a formal issue, subjective preferences, however, represented by the utility function, are central. Preferences are subjective, just as utility derived from consumption is subjective. Choices, therefore, are not rational in the substantial sense, but they are an expression of personal desires and anticipated satisfaction resulting from fulfilling one's preferences. The disappearance of the concept of self-interest is also explained, as 
self-interest choices are rational. A rational egoist, acting in his own interest, will not always maximise his actual desires; he may decide that it is in his interest to abandon certain aspirations.

The choice of subjectivism by standard economics calls for justification. Scanlon (1975, pp. 655-669) provided two arguments:

(1) the subjective criterion of economic choices attributes the highest importance to the sovereignty of individual tastes which can be identified by means of preferences;

(2) the subjective criterion is oriented towards the results of economic activity that correspond to the diversity of needs.

In economics textbooks, the first argument is emphasised as the assumption of consumer sovereignty. For example, Samuelson and Nordhaus (1985, p. 44) say:

The economy is ultimately ruled by two monarchs: consumers and technology. Consumers direct by their innate or learned tastes, as expressed in their dollar votes $[\ldots]$.

This quote shows the application of the taste model in a rather unsophisticated manner since actual, autonomous desires have been replaced by "innate or learned tastes," and their fulfilment depends on technology. At present, it is even claimed that the argument of consumer sovereignty is empty as consumers do not have the knowledge and information enabling them to make choices in the world of high technology (Sirgy \& Chenting, 2000). The idea of consumer sovereignty requires full rationality. The choice theory, however, proves that the consumer can only choose between two substitutable goods.

The second argument for subjectivity has been abandoned in standard economics. Certain needs, such as health and sustenance, belong to the sphere of facts, and in the light of the presented distinctions can be considered as objective and rationally pursued. This view of needs is considered to be at risk of paternalism. However, satisfying actual, and therefore subjective, desires guarantees consumer sovereignty (Griffin, 1998, p. 36).

Various objections are raised against the taste model. In the extreme case, it is rejected in favour of the perception model, which gives precedence to value judgment: first, we assess something as valuable, and then we strive to achieve what is valuable. In this approach, reason and reflection prevail over the objective value of a given object. Revealed values exist independently of subjective desires. Their fulfilment provides deep satisfaction resulting from the understanding of important aspects of reality.

The adoption of the perception model could seriously undermine the axiological foundation of the market economy - negative freedom, as there is a danger of replacing individual, free choices with the arbitrary imposition of what should be chosen as objectively valuable. Although basic needs exist, their satisfaction can 
be varied, and it can change according to a subjective scale. Therefore, objections against the taste model generally do not lead to providing evidence that it needs to be rejected.

Firstly, it is claimed that the subjective choice criterion is satisfactory with regard to an ordering of certain baskets of goods, but it is not sufficiently sensitive to the diversity of needs. Some needs are particularly urgent and important, but preferences do not form a hierarchy. Scanlon (1975) proposes the introduction of the so-called urgency, expressing man's general concern about satisfying basic needs, into the taste model. Sen (1981), however, thinks that a hierarchical ordering of preferences requires meta-preferences. Frankfurt (1971) proposed a multilevel concept of personality. First-order desires result from the biological nature of man, but also from unreflectiveness, giving into impulses, influences and pressure. Frankfurt calls the man who exhibits only desires of the first order "a wanton". "His desires move him to do certain things, without its being true of him either that he wants to be moved by those desires or that he prefers to be moved by other desires" (1971, p. 11). Whereas desires of the second order make a man a person. A person makes decisions based on reflection on first-order desires and how to fulfil them to achieve their own preferences and goals.

In the light of these reservations, the taste model can be used for simple choices which are about biological desires and which even a rat can make.

Secondly, it is said that some desires are peripheral, and their fulfilment does not affect individual well-being. While making choices, a man should not succumb to impulses or rely on fate but should have knowledge about the world and be deeply aware which aspects of reality he considers as valuable. Therefore, desires and preferences are not rejected, but the condition is imposed that they should be rational (Broome, 1991; Griffin, 1988).

Desire is not blind; reason is not inert. (Griffin, 1988, p. 55)

Thirdly, the consumer choice theory based on the taste model faces the criticism related to reactivity. Man changes the order of his preferences in response to changing income and market prices. The possibility that man changes his desires and tastes under the influence of other than economic factors is not accepted. However, such an option cannot be rejected. Human nature is complex, prone to self-evaluation and reflection. Its non-biological component is a factor in the autonomous change of desires and tastes, the reason for actions focused not on the result itself, but on the process, on the route to achievement (Hirschman, 1985; Elster, 1985).

The presented reservations allow us to understand the application of the taste model in economics and its limitations. There is usually no discussion concerning these reservations in American economics textbooks. Only Begg et al. (1993, p. 77) point out that: 
people are not beings as simple as economists assume. Prices, incomes and profits are not the main determinants of our behavior [...] Economics places emphasis on phenomena caused by economic stimuli.

This reservation, however, does not change the general message conveyed by this particular textbook and other American economics textbooks. It was rightly pointed out by Sulejewicz $(2002$, p. 9) that "neoclassical economics [...] does not see the context in which knowledge is created."

\section{Conclusions}

Experimental methods in social sciences cannot be considered as a valuable source of scientific information. They should be combined with other research methods and used systematically among pupils and students as well as among people working in various economic professions. My observations as a lecturer of microeconomics in the first year of studies and business ethics in the fifth year indicate the destructive impact of a decline in the level of cognitive requirements resulting from the prevalence of empirical and "manipulative," as students call them, disciplines. A massive attendance at university and the resulting lack of relations with peers and professors also have an adverse effect.

These observations have been confirmed over the subsequent years of my didactic work. In addition, I have observed a lack of response of students involved in the business activity to ethical arguments. In the course of MBA studies, I covered books of Sandel: Justice (2009) and What Money Can't Buy (2012). In their essays, students disagreed with the arguments presented by Sandel. They repeatedly stated that in Poland, as in the United States of America, expanding the market boundaries to encompass such "goods" as friendship, sterilisation, or egg cells could be considered as assistance given to another person and also that there would always be someone who would choose such forms of making money. Opinions that relativised individual choices were widespread. The students who were the authors of those essays knew the economic reality and I think that relativisation of moral aspects of business facilitated their reconciliation of problematic phenomena over which they had no control over.

Regardless of characteristics of economic studies in Poland, I would argue that the dominance of American economics textbooks requires from a lecturer indepth knowledge of history of economic theory, political and moral philosophy as well as the methodology of economics. Such knowledge is indispensable so that neoclassical economics we teach could be presented as a science which:

(1) studies human actions in the field of economic activity, and thus describes and explains some aspects of multifaceted human activity;

(2) deals with actions, not behaviours; as in the latter case, there is a farreaching simplification of the studied phenomena which reduces them to the relationship between the stimulus and the response; 
(3) arises in the context of pluralistic psychological and philosophical concepts about human nature; the choice of specific concepts, therefore, requires justification;

(4) teleologically explains economic activity as result-oriented actions that satisfy only some goals found in the hierarchically complex structure of human goals.

Wicksteed wrote in 1910 that:

We may either ignore motives altogether or may recognise all motives that are at work, according to the aspect of the matter with which we are concerned at the moment; but in no case may we pick and choose between the motives we will and the motives we will not recognise as affecting economic conditions. (p. 162)

In the first case, microeconomics would become primitive behaviourism, and the person making market choices would not differ from a rat. A small step would separate such microeconomics from social engineering and the resulting "manipulative disciplines" that would create the grounds for intellectual contempt for man. In the latter case, the concept of homo economicus in microeconomics and ways of explaining economic activity should be thoroughly reconsidered. The development of institutional economics, which attempts to explain economic activity in a social context, brings hope in this respect.

\section{References}

Axelrod, R. (1984). The evolution of cooperation. New York: Basic Books.

Baumol, W. J., \& Blinder, A. S. (1988). Economics. San Diego: HBJ.

Begg, D., Fischer, S., \& Dornbusch, R. (1993). Ekonomia. Warszawa: Państwowe Wydawnictwo Ekonomiczne.

Broome, J. (1991). Utility. Economics and Philosophy, 7, 1-12.

Brubaker, E. R. (1975). Free - Ride, Free - Revelation, on Golden Rule? Journal of Law and Economics, 18, 147-161.

Carter, J., \& Irons, M. (1991). Are economist different, and if so, why? Journal of Economic Perspectives, 5, 171-177.

Dawes, R. M., van de Kragt, A. J., \& Orbell, J. M. (1990). Cooperation for benefit for us - Not me, or my conscience. In J. Mansbridge (Ed.), Beyond self-interest (pp. 97-110). Chicago: University of Chicago Press.

Elster, J. (1985). Rationality, morality and collective action. Ethics, 96(1), 136-155.

Etzioni, A. (2015). The moral effects of economic teaching. Sociological Forum, 30(1), 228-233.

Falk, A., Fehr, E., \& Fischbacher, V. (2003). Reasons for conflict: Lessons from bargaining experiments. Journal of Institutional and Theoretical Economics, 159, 171-187. 
Frank R. H., Gilovich, T., Regan, D. T. (1993). Does studying economics inhibit cooperation? Journal of Economic Perspectives, 7(2), 159-177.

Frankfurt, H. G. (1971). Freedom of the will and the concept of a person. Journal of Philosophy, 68(1), 5-20.

Gilbert, D. (1996). The Prisoner's Dilemma and the prisoners of the Prisoner's Dilemma. Business Ethics Quarterly, 6(2), 165-178.

Griffin, J. (1998). Value judgement: Improving our ethical beliefs. Oxford: Clarendon Press.

Güth, W., Schmittberger, R., \& Schwarze, B. (1982). An experimental analysis of ultimatum bargaining. Journal of Economic Behavior and Organization, 3(4), 367-388.

Hardin, G. (1968). The tragedy of the commons. Science, 162, 1243-1248.

Hirschman, A. O. (1985). Against parsimony. Economics and Philosophy, 1(1), 7-21.

Hume, D. (1963). Traktat o naturze ludzkiej. Warszawa: Państwowe Wydawnictwo Naukowe.

Jevons, W. S. (1871). Theory of political economy. London: Macmillan and Co.

Kamerschen, D. R., McKenzie, R. B., \& Nardinelli, C. (1989). Microeconomics. Boston: Houghton Mifflin Co.

Klimczak, B. (2005). Wpływ studiów ekonomicznych na poziom moralny studentów. Annales. Ethics in Economic Life, 8(2), 11-24.

Laidler, D. (1981). Introduction to microeconomics. Oxford: Philip Allan.

Lipsey, R. G., Steiner P. O., Purvis, D. D., \& Courant, P. N. (1990). Economics. New York: Harper and Row.

Marwell, G., \& Ames, R. (1981). Economists free ride. Does anyone else? Journal of Public Economics, 15(3), 295-310.

Olson, M. (1965). The logic of collective action: Public groups and the theory of groups. Cambridge: Harvard University Press.

Ostrom, E. (1990). Governing the commons. The evolution of institutions for collective action. Cambridge: Cambridge University Press.

Poundstone, E. (1992). Prisoner's Dilemma John von Neumann, Game Theory and the puzzle of the bomb. New York: Doubleday.

Robbins, L. (1932). An essay on the nature and significance of economic science. London: Macmillan.

Rosenberg, A. (1992). Economics: Mathematical politics or science of diminishing returns? Chicago: Chicago University Press.

Samuelson, C. D., Messick, D. M., Rutte C. G., \& Wilke H. A. M. (1986). Individual restraint and structural change as solutions to social dilemmas. In H. A. M. Wilke, D. M. Messick, \& C. G. Rutte (Eds.), Experimental social dilemmas (pp. 29-54). Frankfurt am Main: Peter Lang.

Samuelson, P. A., \& Nordhaus, W. D. (1985). Economics. New York: Mc Graw-Hill Book Company.

Sandel, M. J. (2007). Justice: A reader. Oxford-New York: Oxford University Press.

Sandel, M. J. (2012). What money can't buy: The moral limits of markets. New York: Farrar, Straus and Giroux.

Scanlon, T. M. (1975). Preference and urgency. Journal of Philosophy, 72(19), 655-669. 
Sen, A. K. (1981). Plural utility. Proceedings of the Aristotelian Society, 81(1), 193-216.

Sirgy, M. J., \& Chenting, S. (2000). The ethics of consumer sovereignty in an age of high tech. Journal of Business Ethics, 28(1), 1-14.

Smith, A. (1954). Badania nad natura i przyczynami bogactwa narodów. Warszawa: Państwowe Wydawnictwo Naukowe.

Sulejewicz, A. (2002, December 10). Czy nauczanie ekonomii może być szkodliwe? Gazeta SGH, 165.

Varian, H. R. (1995). Mikroekonomia. Warszawa: Wydawnictwo Naukowe PWN.

Wicksteed, P. H. (1910). Common sense of political economy. London: Macmillan and Co. 